Terakreditasi: SK No.: 60/E/KPT/2016

Website : http://ejournal.undip.ac.id/index.php/reaktor/

Reaktor, Vol. 17 No. 1, Maret Tahun 2017, Hal. 1-8

\title{
Optimasi Proses Ozonasi pada Depolimerisasi к-Karagenan dengan Metode Respon Permukaan
}

\author{
Aji Prasetyaningrum*), Ratnawati Ratnawati, dan Bakti Jos \\ Departemen Teknik Kimia, Fakultas Teknik Universitas Diponegoro \\ Jl. Prof. Soedarto, SH, Tembalang, Semarang \\ Telp./Fax. (024)7460058 / (024)76480675 \\ ${ }^{*}$ Penulis korespondensi: aji.prasetyaningrum@che.undip.ac.id
}

\begin{abstract}
OPTIMIZATION OF OZONATION PROCESS FOR K-CARRAGEENAN DEPOLYMERIZATION USING RESPONSE SURFACE METHODOLOGY. The objective of this research is to optimize the operating parameters in depolymerization of $\kappa$-carrageenan by ozone treatment. The optimization is done by using Box-Bhenken Design (BBD) model with ozonation time (5-15 minute), $\mathrm{pH}$ (3-11) and temperature $\left(20-40^{\circ} \mathrm{C}\right)$ as the independent variables. The response of ozonation process is the degree of depolymerization of $\kappa$-carrageenan (DP). The initial molecular weight of refined $\kappa$-karagenan was $271 \mathrm{kDa}$. The $\kappa$-carrageenans powder was completely dissolved in distilled water to form 1\% (weight/volume). The experiments were carried out in a $2000 \mathrm{ml}$ of a glass reactor with an ozone gas sparger. The inlet ozone concentration was $80 \pm 2$ ppm. The result shows that ozonation time, $\mathrm{pH}$, and temperature have significant effects during ozonation process $(p<0.05)$. Analysis of variance shows that the experimental data fit the model very well with the $R^{2}$ value of 0.98 . The optimum conditions during ozonation process are achieved at the reaction time of $15 \mathrm{~min}$, ozonation $\mathrm{pH}$ of 3 and reaction temperature of $25^{\circ} \mathrm{C}$. Under these optimum conditions the DP of $\kappa$ carrageenan is $91.513 \%$.
\end{abstract}

Keywords: depolymerization; $\kappa$-carrageenan; optimization; ozonation process

\begin{abstract}
Abstrak
Tujuan penelitian ini adalah menentukan kondisi optimum parameter operasi depolimerisasi $\kappa$ karagenan dengan perlakuan ozonasi. Optimasi dilakukan dengan menggunakan model statistika Box-Bhenken Design (BBD) dengan variabel yang digunakan yaitu waktu ozonasi (5-15 menit), pH (3-11), dan suhu $\left(20-40^{\circ} \mathrm{C}\right)$. Respon dari proses ozonasi adalah derajat depolimerisasi $\kappa$-karagenan (DP). Berat molekul awal refined $\kappa$-karagenan adalah 271 kDa. Sampel $\kappa$-karagenan dilarutkan secara sempurna dalam air distilasi dan konsentrasi diatur 1\% (berat/volume). Percobaan dilakukan dalam reaktor gelas volume $2000 \mathrm{ml}$ yang dilengkapi dengan sparger gas ozon. Konsentrasi gas ozon yang masuk adalah $80 \pm 2$ ppm. Hasil penelitian menunjukkan bahwa waktu ozonasi, pH, dan suhu berpengaruh secara signifikan terhadap proses ozonasi $(p<0,05)$. Analisis varian menghasilkan ketelitian yang tinggi antara data eksperimen dan prediksi, dengan nilai koefisien $R^{2}=0,98$. Kondisi optimum diperoleh pada waktu ozonasi 15 menit, pH ozonasi 3, dan temperatur reaksi $25^{\circ} \mathrm{C}$. Pada kondisi optimum ini diperoleh DP $\kappa$-karagenan sebesar 91,513\%.
\end{abstract}

Kata kunci: depolimerisasi; $\kappa$-carrageenan; optimasi; proses ozonasi 
How to Cite This Article: Prasetyaningrum, A., Ratnawati, R., dan Jos, B., (2017), Optimasi Proses Ozonasi pada Depolimerisasi $\kappa$-Karagenan dengan Metode Respon Permukaan, Reaktor, 17(1), 1-8, http://dx.doi.org/ 10.14710/reaktor.17.1.1-8

\section{PENDAHULUAN}

к-karagenan adalah nama umum polisakarida yang diperoleh dari ekstraksi alga merah (Rhodophyta). Struktur molekul $\kappa$-karagenan terdiri dari ikatan berulang antara gugus galaktosa dengan 3,6-anhidrogalaktosa (3,6 AG). Keduanya baik yang berikatan dengan sulfat maupun tidak, dihubungkan dengan ikatan glikosidik $\alpha-(1,3)$ dan $\beta-(1,4)$. $\kappa-$ karagenan disebut juga polisakarida galaktan sulfat (Sulfated Galactans) karena mengandung gugus galaktosa dan sulfat serta residu karbohidrat seperti xylose, glukosa, asam uronic, kelompok metil eter dan piruvat. $\kappa$-karagenan memiliki ukuran berat molekul yang tinggi, yaitu antara 400-600 kDa. Struktur molekul $\kappa$-karagenan disajikan pada Gambar 1.

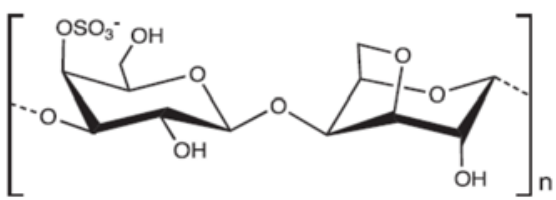

Gambar 1. Struktur molekul $\kappa$-karagenan (Campo dkk., 2009)

$\kappa$-karagenan digunakan secara luas dalam industri makanan karena sifat fungsional yang baik (thickening, gelling dan stabilizing), mengontrol viskositas dan memperbaiki tekstur pada bahan makanan, serta sebagai pengikat dan stabilisator dalam industri pengolahan daging (Necas dan Bartosikova, 2013; Bixler dan Porse, 2010). Meskipun $\kappa$-karagenan mempunyai fungsi yang cukup banyak, namun berat molekul dan viskositasnya yang tinggi membatasi dalam penggunaan dan aplikasinya yang lebih luas. Dengan mengubah $\kappa$-karagenan berat molekul tinggi (KBMT) menjadi $\kappa$-karagenan berat molekul rendah (KBMR) akan meningkatkan bioavailabilitas dan memperluas aplikasi karagenan dalam bidang farmasi dan biomedis (Pomin, 2010; Jiao dkk., 2011; Wijesekara dkk., 2011).

$\kappa$-karagenan berat molekul rendah memberikan peranan yang signifikan terhadap aktivitas biologi diantaranya sebagai anti-coagulant (Silva dkk., 2010), anti-tumor (Yuan dan Song, 2005; Haijin dkk., 2003), anti-kanker (Raman dan Doble, 2015), antiangiogenic (Yao dkk., 2014; de Souza dkk., 2012), anti-virus (Kalitnik dkk., 2013; Wang dkk., 2012; Yamada dkk., 2000), dan antioksidan (Qi dkk., 2005). Alasan utama penggunaan $\kappa$-karagenan dalam bidang biomedis adalah $\kappa$-karagenan memiliki sifat elektronegatif dengan kerapatan muatan yang tinggi akibat adanya ester sulfat yang memungkinkan terjadinya interaksi elektrostatik dengan protein tertentu yang menyebabkan munculnya fungsi aktivitas biologi senyawa tersebut. Ukuran berat molekul KBMR untuk anti HIV adalah 51-54 kDa, anti tumor sebesar 1,2 $\mathrm{kDa}$, promotor pada pertumbuhan tanaman $<10 \mathrm{kDa}$ dan untuk anti bakteri adalah 100-120 kDa (Abad dkk., 2010). KBMR menunjukkan aktivitas antioksidan yang lebih kuat dibandingkan KBMT, karena dapat berinteraksi dengan sel lebih efisien dan efektif. Aktivitas biologi dari KBMR tergantung pada ukuran berat molekul, derajat sulfatasi, dan percabangan glikosida (Pomin, 2010; Wijesekara dkk., 2011).

Proses depolimerisasi $\kappa$-karagenan dapat dilakukan dengan beberapa metode, yaitu depolimerisasi thermal (Lai dkk., 2000), hidrolisis dengan asam (Sun dkk., 2015; Wang dkk., 2012; Yuan dan Song, 2005; Karlsson dan Singh, 1999; Singh dan Jacobson, 1994), dan hidrolisis secara enzimatik (Duan dkk., 2016; Raman dan Doble, 2015; Wu, 2012; Haijin dkk., 2003). Beberapa teknik depolimerisasi yang lain adalah dengan microwave (Zhou dkk., 2006), gelombang ultrasonik (Ratnawati dkk., 2016; Taghizadeh dan Abdollahi, 2015; Yamada dkk., 2000), perlakuan iradiasi (Abad dkk., 2010; Qi dkk., 2005), dan oksidasi menggunakan $\mathrm{H}_{2} \mathrm{O}_{2}$ (Sun dkk., 2015; Zuniga dkk., 2006).

Proses depolimerisasi molekul $\kappa$-karagenan dengan hidrolisis kimiawi memiliki beberapa kelemahan diantaranya menggunakan bahan kimia konsentrasi tinggi yang residunya mencemari lingkungan. Depolimerisasi dengan gelombang ultrasonik dan microwave membutuhkan peralatan dengan spesifikasi tertentu dan biaya operasi mahal. Hidrolisis enzimatik memiliki kelemahan, yaitu reaksi cukup kompleks dan enzim yang spesifik (carrageenase) tidak sesuai pertumbuhannya pada iklim tropis. Proses radiasi mengakibatkan terjadinya perubahan struktur kimia dan cenderung menghilangkan gugus sulfat pada KBMR yang diketahui memiliki peranan signifikan dalam aktivitas biologi (Relleve dkk., 2005).

Beberapa penelitian terbaru menunjukkan potensi ozon pada proses depolimerisasi makromolekul polisakarida diantaranya depolimerisasi starch (Sandhu dkk., 2012), kitosan (Kabal'nova dkk., 2001), tepung cassava (Klein dkk., 2014). Reaksi ozonasi pada $\kappa$-karagenan dapat menurunkan berat molekul tetapi tidak mengubah gugus fungsionalnya (Prasetyaningrum dkk., 2017a). Konstanta laju reaksi depolimerisasi $\kappa$-karagenan dengan ozonasi cukup tinggi dan setara dengan depolimerisasi secara thermal (Prasetyaningrum dkk., 2017b). Ozon adalah oksidan kuat yang tidak meninggalkan residu pada bahan, sehingga aman digunakan untuk pengolahan bahan makanan dan obat-obatan. Kelebihan ozon adalah ozon akan terurai dengan cepat menjadi oksigen dan tidak meninggalkan residu pada bahan, sehingga proses ozonasi sering disebut sebagai "green technology" (Seydim dan Greene, 2004). 
Pada reaksi ozonasi, tingkat depolimerisasi $\kappa$ karagenan dipengaruhi oleh beberapa faktor diantaranya adalah laju alir gas ozon, waktu reaksi, $\mathrm{pH}$, suhu, dan konsentrasi polisakarida (Loures dkk., 2013; Lemeune dkk., 2000). Mekanisme depolimerisasi larutan polisakarida dengan ozonasi dapat dijelaskan melalui tiga tahapan reaksi, yaitu: 1) depolimerisasi ozonolitik ikatan $\beta$-D-glikosida, 2) depolimerisasi oksidatif oleh radikal hidroksil yang terbentuk dalam air, dan 3) hidrolisis pada kondisi asam. Reaksi depolimerisasi oleh radikal hidroksil dan hidrolisis asam terjadi secara nonselektif, sedangkan pada reaksi langsung yaitu depolimerisasi ozonolitik terjadi secara selektif. Diantara ketiga reaksi tersebut mekanisme depolimerisasi polisakarida yang paling dominan adalah reaksi pertama, yaitu depolimerisasi selektif ikatan $\beta$-D-glikosida dengan ozon (Wang dkk., 1999). Secara umum, pemutusan ikatan glikosida pada $\kappa$-karagenan disajikan pada Gambar 2.

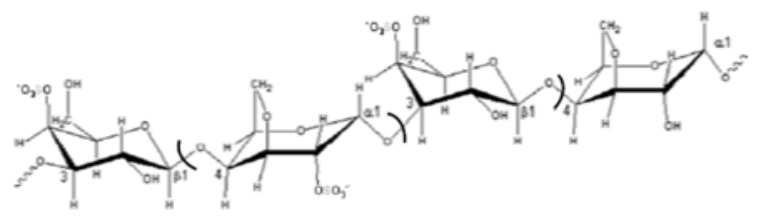

Gambar 2. Pemutusan ikatan glikosida pada $\kappa$ karagenan dengan reaksi ozonasi (Abad dkk., 2010)

Modifikasi dan pengembangan proses ozonasi yang efektif dan efisien perlu diteliti untuk menghasilkan produk KBMR. Penelitian ini bertujuan untuk menentukan kondisi optimum proses ozonasi (waktu, $\mathrm{pH}$ dan suhu ozonisasi) terhadap depolimerisasi $\kappa$-karagenan. Optimasi menggunakan metode respon permukaan dengan rancangan model statistika Box-Bhenken Design (BBD) dan desain eksperimen menggunakan perangkat lunak statistika 6 .

\section{BAHAN DAN METODE Bahan}

Bahan baku yang digunakan untuk penelitian ini adalah commercial $\kappa$-karagenan dari CV. Karagen Indonesia. $\kappa$-karagenan yang berbentuk serbuk dimurnikan terlebih dahulu dengan cara melarutkan dalam air distilasi dan dipanaskan sampai suhu $70^{\circ} \mathrm{C}$. Selanjutnya dilakukan penyaringan dengan pompa vakum untuk memisahkan larutan karagenan dan pengotor. Larutan hasil filtrasi diendapkan kembali dengan isopropil alkohol sehingga diperoleh refined $\kappa$ karagenan. Selama proses ozonasi kondisi $\mathrm{pH}$ diatur pada $\mathrm{pH} \mathrm{3,} \mathrm{7,} \mathrm{dan} 11$ dengan menambahkan larutan $\mathrm{HCl}$ kadar 37\% (E. Merck Cat. No. 100317) atau larutan $\mathrm{NaOH}$ (E. Merck Cat. No. 104698). Larutan penyangga buffer solution pH 7 ditambahkan untuk menjaga kestabilan larutan $\kappa$-karagenan dan mencegah supaya tidak terjadi penggumpalan atau agregasi selama proses ozonasi.

\section{Proses Ozonasi}

Reaksi ozonasi dilakukan dengan melarutkan refined $\kappa$-karagenan dalam air distilasi dengan konsentrasi $1 \%$ (berat/volume). Proses ozonasi dilakukan pada reaktor gelas dengan volume $2000 \mathrm{ml}$ yang dilengkapi spager untuk mendistribusikan gas ozon. Laju alir gas ozon dijaga konstan dengan kecepatan 3 L.menit ${ }^{-1}$. Gas ozon dihasilkan dari peralatan pembangkit ozon yang diproduksi oleh PT. Dipo Teknologi Indonesia, dengan spesifikasi tegangan $\pm 30 \mathrm{kV}$ dan konsentrasi ozon terlarut sebesar $80 \pm 2 \mathrm{mg} . \mathrm{L}^{-1}$. Percobaan dilakukan dengan variabel waktu ozonasi $(5,10$, dan 15 menit), $\mathrm{pH}$ awal reaksi (3, 7, dan 11), serta suhu larutan $\kappa$-karagenan selama ozonasi $\left(20,30\right.$, dan $\left.40^{\circ} \mathrm{C}\right)$. Pengukuran $\mathrm{pH}$ reaksi menggunakan $\mathrm{pH}$ meter (Hanna Instruments HI 98107). Selanjutnya $\kappa$-karagenan yang telah diozonasi diendapkan dengan alkohol dan dikeringkan pada suhu $60^{\circ} \mathrm{C}$ selama 8 jam sehingga diperoleh produk KBMR. Produk KBMR tersebut ditentukan ukuran berat molekulnya untuk menentukan derajat depolimerisasi selama reaksi ozonasi.

\section{Penentuan Ukuran Berat Molekul}

Penentuan ukuran berat molekul rata-rata dari produk KBMR dilakukan dengan metode pengukuran viskositas intrinsik, seperti dijelaskan pada persamaan Mark Houwink (persamaan (1)).

$$
[\eta]=k_{M H} M^{a}
$$

dimana konstanta $k_{M H}$ dan $a$ untuk $\kappa$-karagenan adalah $k_{M H}=0,00598$ dan $a=0,90$ (Lii dkk., 1999).

Viskositas intrinsik $([\eta])$ dihitung dari nilai viskositas spesifik $\left(\eta_{s p}\right)$ menggunakan Persamaan (2). Alat yang digunakan untuk mengukur nilai viskositas spesifik adalah viskosimeter kapiler Ubbelohde (tipe 531 030c Schott-Gerate, Germany). Pengukuran viskositas dijaga pada suhu $45,0 \pm 0,1^{\circ} \mathrm{C}$. Viskositas intrinsik merupakan nilai intercept dari persamaan Huggins dan Kraemer (persamaan 2).

$$
\frac{\eta_{\mathrm{sp}}}{\mathrm{c}}=[\eta]+\mathrm{k}_{\mathrm{H}}[\eta]^{2} \mathrm{c}
$$

dimana $\eta_{\mathrm{sp}},[\eta], \mathrm{k}_{\mathrm{H}}$, dan $\mathrm{c}$ masing-masing adalah viskositas spesifik, viskositas intrinsik, konstanta Huggins dan konsentrasi larutan $\kappa$-karagenan. Viskositas spesifik $\left(\eta_{\mathrm{sp}}\right)$ dan konstanta Huggins $\left(\mathrm{k}_{\mathrm{H}}\right)$ adalah tidak berdimensi. Sedangkan viskositas intrinsik ([ๆ]) memiliki satuan $\mathrm{mL} \mathrm{g}^{-1}$ dan konsentrasi larutan $\kappa$-karagenan (c) memiliki satuan $\mathrm{g} \mathrm{mL}^{-1}$. Nilai $\mathrm{k}_{\mathrm{H}}$ untuk larutan $\kappa$-karagenan adalah 0,35 (Vreeman dkk., 1980).

Depolimerisasi (DP) dinyatakan sebagai penurunan nilai berat molekul $\kappa$-karagenan setelah ozonasi dibandingkan dengan berat molekul awal, dan dapat dihitung menggunakan persamaan (3):

$$
\text { DP }(\%)=\left(M_{i}-M_{t}\right) / M_{i} \times 100
$$

dimana $\mathrm{M}_{\mathrm{i}}$ adalah berat molekul $\kappa$-karagenan pada saat awal dan $\mathrm{M}_{\mathrm{t}}$ adalah berat molekul $\kappa$-karagenan setelah ozonasi selama $(\mathrm{t})$ menit. 


\section{Analisis Data}

Rancangan percobaan didasarkan pada konstruksi model Box-Behnken, yang terdiri dari 3 faktor, 1 blok dan 15 run. Jenis variabel proses dan rancangan percobaan dengan metode respon permukaan seperti disajikan pada Tabel 1.

Tabel 1. Rancangan penelitian dengan metode respon permukaan

\begin{tabular}{|c|c|c|c|c|c|c|c|}
\hline \multirow[b]{2}{*}{ Run } & \multicolumn{3}{|c|}{ Kode } & \multicolumn{3}{|c|}{ Faktor } & \multirow{2}{*}{$\begin{array}{l}\text { Respon } \\
\text { DP (\%) }\end{array}$} \\
\hline & $\mathrm{X}_{1}$ & $\mathrm{X}_{2}$ & $X_{3}$ & $\begin{array}{l}\text { Waktu } \\
\text { /menit }\end{array}$ & $\mathrm{pH}$ & $\begin{array}{c}\text { Suhu } \\
{ }^{\circ} \mathrm{C}\end{array}$ & \\
\hline 1 & -1 & -1 & 0 & 5 & 3 & 30 & $\mathrm{Y}_{1}$ \\
\hline 2 & 1 & -1 & 0 & 15 & 3 & 30 & $\mathrm{Y}_{2}$ \\
\hline 3 & -1 & 1 & 0 & 5 & 11 & 30 & $\mathrm{Y}_{3}$ \\
\hline 4 & 1 & 1 & 0 & 15 & 11 & 30 & $\mathrm{Y}_{4}$ \\
\hline 5 & -1 & 0 & -1 & 5 & 7 & 20 & $\mathrm{Y}_{5}$ \\
\hline 6 & 1 & 0 & -1 & 15 & 7 & 20 & $\mathrm{Y}_{6}$ \\
\hline 7 & -1 & 0 & 1 & 5 & 7 & 40 & $\mathrm{Y}_{7}$ \\
\hline 8 & 1 & 0 & 1 & 15 & 7 & 40 & $\mathrm{Y}_{8}$ \\
\hline 9 & 0 & -1 & -1 & 10 & 3 & 20 & $\mathrm{Y}_{9}$ \\
\hline 10 & 0 & 1 & -1 & 10 & 11 & 20 & $Y_{10}$ \\
\hline 11 & 0 & -1 & 1 & 10 & 3 & 40 & $\mathrm{Y}_{11}$ \\
\hline 12 & 0 & 1 & 1 & 10 & 11 & 40 & $Y_{12}$ \\
\hline 13 & 0 & 0 & 0 & 10 & 7 & 30 & $Y_{13}$ \\
\hline 14 & 0 & 0 & 0 & 10 & 7 & 30 & $\mathrm{Y}_{14}$ \\
\hline 15 & 0 & 0 & 0 & 10 & 7 & 30 & $Y_{15}$ \\
\hline
\end{tabular}

Hubungan antara variabel bebas terhadap respon dapat dinyatakan dalam persamaan polinomial orde 2 yang disajikan pada persamaan (4) (Vuong dkk., 2011).

$$
\begin{aligned}
Y= & \beta_{0}+\sum_{i=1}^{k} \beta_{i} X_{i}+\sum_{\substack{i=1 \\
i<j}}^{k-1} \sum_{j=2}^{k} \beta_{i j} X_{i} X_{j}+ \\
& \sum_{i=1}^{k} \beta_{i i} X_{i}^{2}
\end{aligned}
$$

dimana $\mathrm{X}_{\mathrm{i}}$ dan $\mathrm{X}_{\mathrm{j}}$ adalah variabel bebas dan $Y$ adalah respon. Sedangkan $\beta_{\mathrm{o}}, \beta_{\mathrm{i}}, \beta_{\mathrm{ii}}, \beta_{\mathrm{ij}}$ adalah koefisien regresi dan $\mathrm{k}$ adalah jumlah variabel. Terdapat tiga variabel bebas yaitu waktu ozonasi $\left(\mathrm{X}_{1}\right), \mathrm{pH}\left(\mathrm{X}_{2}\right)$, suhu $\left(\mathrm{X}_{3}\right)$ dan satu variabel respon yaitu derajat depolimerisasi (DP) yang dinyatakan sebagai $Y$, seperti disajikan pada persamaan (5).

$$
\begin{aligned}
Y= & \beta_{0}+\beta_{1} X_{1}+\beta_{2} X_{2}+\beta_{3} X_{3}+\beta_{12} X_{1} X_{2}+ \\
& \beta_{13} X_{1} X_{3}+\beta_{23} X_{2} X_{3}+\beta_{11} X_{1}^{2}+\beta_{22} X_{2}^{2}+\beta_{33} X_{3}^{2}
\end{aligned}
$$

\section{HASIL DAN PEMBAHASAN \\ Analisis Statistika}

Pada penelitian ini digunakan metode faktorial design untuk mengevaluasi pengaruh masing-masing variabel dan pengaruh interaksi antara satu variabel dengan variabel yang lain terhadap respon. Analisis statistika dan penyajian grafik respon permukaan dalam bentuk tiga dimensi (3D) dilakukan dengan bantuan program Statistika 6,0. Hasil analisis data eksperimen dan prediksi dari variabel waktu, $\mathrm{pH}$ dan suhu ozonasi terhadap respon nilai DP $\kappa$-karagenan disajikan pada Tabel 2.

Persamaan polinomial orde 2 yang menjelaskan hubungan antara variabel bebas dan respon, yang disajikan pada persamaan (6).

$$
\begin{aligned}
\mathrm{Y}= & 16,94+4,59 \mathrm{X}_{1}-1,00 \mathrm{X}_{2}+2,88 \mathrm{X}_{3}+0,21 \mathrm{X}_{1} \mathrm{X}_{2} \\
& +0,01 \mathrm{X}_{1} \mathrm{X}_{3}+0,01 \mathrm{X}_{2} \mathrm{X}_{3}-0,15 \mathrm{X}_{1}^{2}-0,42 \mathrm{X}_{2}^{2}-0,07 \mathrm{X}_{3}^{2}
\end{aligned}
$$

Koefisien $\left(\mathrm{R}^{2}\right)$ merupakan salah satu parameter yang digunakan untuk mengetahui keakuratan model atau kedekatan nilai data eksperimen dan prediksi (Aksoy dan Sagol, 2016; Regti dkk., 2017). Tabel 3 menunjukkan kedekatan nilai prediksi dengan data eksperimen yang diperoleh. Berdasarkan analisis varian nilai koefisien $\mathrm{R}^{2}$ yang diperoleh adalah 0,98 . Hal ini menunjukkan bahwa terdapat $98 \%$ kesesuaian antara data eksperimen dan data prediksi. Model dapat dinyatakan sangat signifikan apabila mempunyai nilai probabilitas $(p<0,05)$.

Tabel 2. Rancangan variabel dengan metode BBD dan nilai respon (DP) $\kappa$-karagenan

\begin{tabular}{ccrccc}
\hline Run & $\begin{array}{c}\text { Waktu } \\
\text { (menit) }\end{array}$ & pH & $\begin{array}{c}\text { Suhu } \\
\left({ }^{\circ} \mathrm{C}\right)\end{array}$ & Eksperimen & Prediksi \\
\hline 1 & 5 & 3 & 30 & 63,47 & 62,36 \\
2 & 15 & 3 & 30 & 91,51 & 86,44 \\
3 & 5 & 11 & 30 & 14,02 & 19,10 \\
4 & 15 & 11 & 30 & 59,04 & 60,15 \\
5 & 5 & 7 & 20 & 52,03 & 50,05 \\
6 & 15 & 7 & 20 & 79,70 & 81,69 \\
7 & 5 & 7 & 40 & 33,58 & 31,60 \\
8 & 15 & 7 & 40 & 63,10 & 65,08 \\
9 & 10 & 3 & 20 & 77,86 & 80,95 \\
10 & 10 & 11 & 20 & 48,34 & 45,25 \\
11 & 10 & 3 & 40 & 59,41 & 62,50 \\
12 & 10 & 11 & 40 & 31,73 & 28,64 \\
13 & 10 & 7 & 30 & 67,53 & 67,53 \\
14 & 10 & 7 & 30 & 67,53 & 67,53 \\
15 & 10 & 7 & 30 & 67,53 & 67,53 \\
\hline
\end{tabular}

\section{Pengaruh Variabel Proses pada Ozonasi Larutan к-karagenan}

Pengaruh parameter proses atau variabel ozonasi (waktu, $\mathrm{pH}$ dan suhu) diuji terhadap \%DP $\kappa-$ karagenan. Hasil analisis statistika menunjukkan bahwa fungsi linier dari waktu $\left(\mathrm{X}_{1}\right), \mathrm{pH}\left(\mathrm{X}_{2}\right)$ dan suhu ozonasi $\left(\mathrm{X}_{3}\right)$ memberikan pengaruh yang signifikan terhadap $(5)$ depolimerisasi $\kappa$-karagenan $(p<0,05)$. Demikian juga fungsi kuadratik dari $\mathrm{pH}\left(\mathrm{X}_{2}^{2}\right)$ dan suhu ozonasi $\left(\mathrm{X}_{3}^{2}\right)$. Semua interaksi antara variabel yaitu waktu-pH $\left(\mathrm{X}_{1} \mathrm{X}_{2}\right)$, waktu-suhu $\left(\mathrm{X}_{1} \mathrm{X}_{3}\right)$ serta $\mathrm{pH}$ suhu $\left(\mathrm{X}_{2} \mathrm{X}_{3}\right)$ tidak memberikan pengaruh yang signifikan terhadap DP $\kappa$-karagenan. Data signifikansi parameter variabel ozonasi (waktu, $\mathrm{pH}$ dan suhu) terhadap respon (\%DP) $\kappa$-karagenan disajikan pada Tabel 3. Nilai MS Residual menyatakan selisih antara nilai eksperimen dan nilai prediksi yang diperoleh dari model. Pada penelitian ini diperoleh nilai MS residual adalah 21,55 sehingga dapat disimpulkan bahwa model yang disusun cukup akurat untuk menjelaskan kedekatan antara hasil eksperimen dan model.

Ozonasi menyebabkan depolimerisasi $\kappa-$ karagenan. Hubungan antara variabel dalam profil 3 dimensi antara waktu, $\mathrm{pH}$ dan suhu terhadap nilai DP $\kappa$-karagenan disajikan pada Gambar 2. 
Tabel 3. Hasil Analisa ANOVA

\begin{tabular}{|c|c|c|c|c|c|c|}
\hline & Koef. & SS & $\mathrm{dF}$ & MS & $\mathrm{F}$ & $\mathrm{p}$ \\
\hline$\beta_{0}$ & 16,94 & & & & & \\
\hline$\beta_{1}$ & 4,59 & 2120,90 & 1 & 2120,90 & 98,30 & 0,00018 \\
\hline$\beta_{1}^{2}$ & $-0,15$ & 55,43 & 1 & 55,43 & 2,57 & 0,16987 \\
\hline$\beta_{2}$ & $-1,00$ & 2419,10 & 1 & 2419,10 & 112,12 & 0,00013 \\
\hline$\beta_{2}^{2}$ & $-0,42$ & 162,89 & 1 & 162,89 & 7,55 & 0,04042 \\
\hline$\beta_{3}$ & 2,88 & 614,44 & 1 & 614,44 & 28,48 & 0,00310 \\
\hline$\beta_{3}{ }^{2}$ & $-0,07$ & 158,40 & 1 & 158,40 & 7,34 & 0,04230 \\
\hline$\beta_{1} \beta_{2}$ & 0,21 & 72,03 & 1 & 72,03 & 3,34 & 0,12723 \\
\hline$\beta_{1} \beta_{3}$ & 0,01 & 0,85 & 1 & 0,85 & 0,04 & 0,85039 \\
\hline$\beta_{2} \beta_{3}$ & 0,01 & 0,85 & 1 & 0,85 & 0,04 & 0,85039 \\
\hline \multicolumn{2}{|c|}{ Error } & 107,88 & & & & \\
\hline \multirow{2}{*}{\multicolumn{2}{|c|}{$\begin{array}{c}\text { Total SS } \\
\text { MS Residual }\end{array}$}} & 5666,50 & & \multirow{2}{*}{\multicolumn{2}{|c|}{$\begin{array}{c}\mathrm{R}^{2} \\
\text { Adj } R^{2}\end{array}$}} & 0,98 \\
\hline & & 21,55 & & & & 0,95 \\
\hline
\end{tabular}
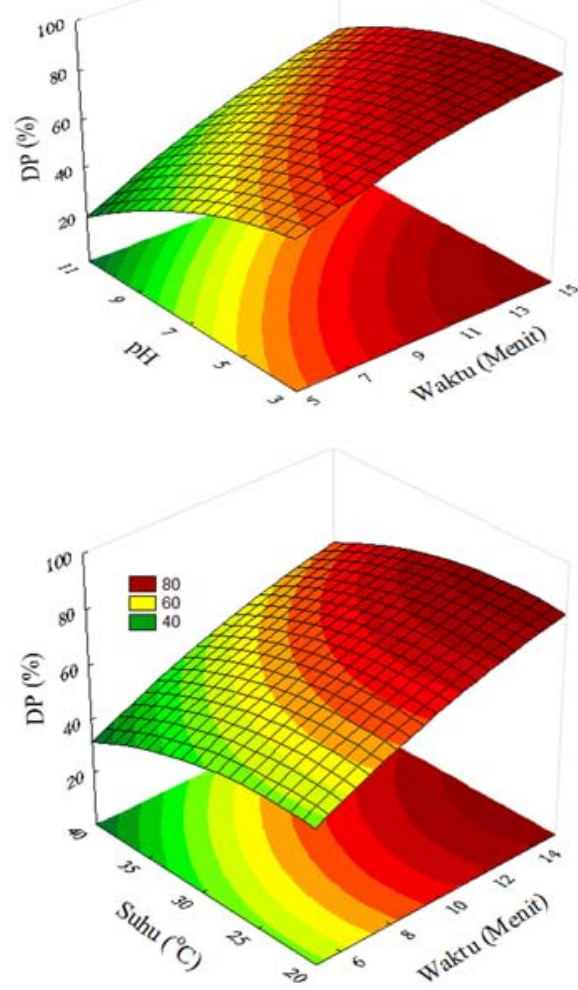

(b)

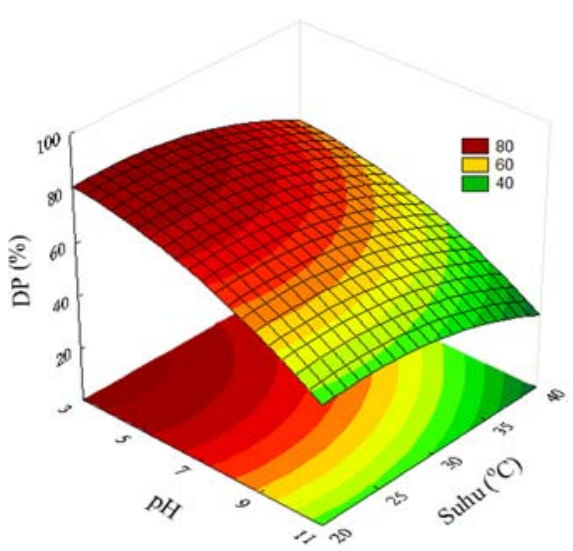

Gambar 2. Profil 3 dimensi ozonasi к-karagenan: (a) pengaruh waktu dan $\mathrm{pH}$, (b) pengaruh waktu dan suhu, (c) Pengaruh $\mathrm{pH}$ dan suhu
Pada penelitian ini, perlakuan $\mathrm{pH}$ yang rendah selama ozonasi memberikan hasil yang signifikan terhadap depolimerisasi $\kappa$-karagenan. Pada perlakuan pH 3 dan pemberian dosis ozon sebesar $80 \pm 2 \mathrm{ppm}$ selama 15 menit, DP $\kappa$-karagenan mencapai 91,51\%. Sebaliknya, pada perlakuan $\mathrm{pH} 11$, DP $\kappa$-karagenan hanya mencapai $59,04 \%$ untuk pemberian dosis ozon dan waktu ozonasi yang sama. Hal ini menunjukkan perlakuan oksidasi dengan ozon pada $\mathrm{pH}$ rendah atau kondisi asam memberikan peranan penting selama ozonasi. Penelitian tentang ozonasi kitosan yang dilakukan oleh Seo dkk. (2007) menunjukkan kecenderungan yang sama, yaitu kenaikan waktu ozonasi dan perlakuan ozonasi pada kondisi asam akan meningkatkan derajat depolimerisasi. Klein dkk. (2014) juga menyatakan bahwa pH 3,5 adalah yang paling efektif untuk menurunkan viskositas dan pemutusan ikatan rangkap tepung cassava dengan proses ozonasi.

Pada perlakuan $\mathrm{pH}$, suhu dan konsentrasi ozon yang tetap terdapat kecenderungan bahwa laju reaksi reaksi depolimerisasi akan naik seiring dengan kenaikan waktu ozonasi. Semakin lama waktu reaksi, maka semakin tinggi kesempatan kontak antara ozon dengan $\kappa$-karagenan. Tabel 2 menunjukkan nilai pengaruh waktu sebagai fungsi linier sangat signifikan pada proses ozonasi $(\mathrm{p}=0,00018)$. Semakin lama waktu ozonasi akan meningkatkan DP $\kappa$-karagenan. Pada $\mathrm{pH}$ 7 dan suhu $20^{\circ} \mathrm{C}$ DP $\kappa$-karagenan mengalami kenaikan yang signifikan dari $52,03 \%$ menjadi $79,70 \%$ jika waktu ozonasi meningkat dari 5 menit menjadi 15 menit.

Kelarutan ozon akan meningkat apabila proses ozonasi dilakukan pada suhu yang rendah. Pada perlakuan pH 7 dan waktu ozonasi selama 15 menit DP $\kappa$-karagenan mengalami kenaikan dari 63,10\% menjadi $79,70 \%$ jika temperatur reaksi diturunkan dari $40^{\circ} \mathrm{C}$ menjadi $20^{\circ} \mathrm{C}$. Simoes dan Castro (2001) menyatakan bahwa perlakuan $\mathrm{pH}$ dan suhu yang rendah dapat menghambat produksi radikal, sehingga memperpanjang waktu tinggal ozon di dalam air.

Depolimerisasi polisakarida yang melibatkan ozon lebih selektif dibanding depolimerisasi akibat radikal hidroksil dan hidrolisis asam (Wang dkk., 1999). Menurut Kabal'nova dkk. (2000) selama proses ozonasi terjadi pemutusan ikatan glikosidik dan memicu pembentukan gugus karbonil dan karboksil. Pembentukan gugus karbonil akibat putusnya ikatan pada unit $\mathrm{C}(1)$, sedangkan gugus karboksil diduga terbentuk pada C(4) 3,6-anhidro-D-galaktosa. Reaktivitas ozon dan jumlah radikal yang terbentuk dalam sistem merupakan faktor utama yang mempengaruhi proses depolimerisasi.

Beberapa peneliti mengembangkan metode respon permukaan untuk menentukan kondisi optimum pada beberapa proses kimia. Hadiyanto dan Sutrisnohadi (2016) menggunakan metode respon permukaan untuk menentukan kondisi optimum pada ekstraksi zat phycocyianin dari spirulina. Zhang dkk. (2009) menggunakan metode respon permukaan untuk 
menentukan kondisi optimum ekstraksi minyak dari bubuk almond. Optimasi reaksi ozonasi diperlukan untuk memperoleh kondisi optimum pada depolimerisasi $\kappa$-karagenan. Optimasi dapat dilakukan dengan menggunakan response desirability profiling yang disediakan oleh perangkat lunak Statistica 6 . Hasil optimasi proses depolimerisasi $\kappa$-karagenan dengan ozonasi disajikan pada Gambar 3.

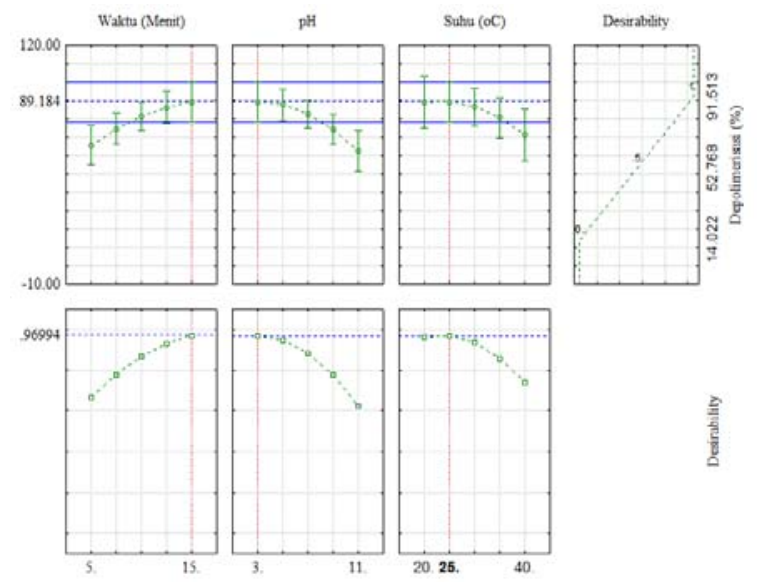

Gambar 3. Kondisi optimum depolimerisasi $\kappa-$ karagenan dengan ozonasi

Semakin lama waktu ozonasi terjadi kecenderungan peningkatan DP $\kappa$-karagenan. Di sisi lain, semakin tinggi $\mathrm{pH}$ dan suhu ozonasi mengakibatkan penurunan nilai DP $\kappa$-karagenan. Nilai atau kondisi optimum diperoleh dengan membaca titik perpotongan antara variabel waktu, $\mathrm{pH}$ dan suhu yang menghasilkan nilai DP $\kappa$-karagenan yang tertinggi. Kondisi optimum diperoleh pada waktu ozonasi 15 menit, $\mathrm{pH} 3$ dan suhu $25^{\circ} \mathrm{C}$ dengan nilai respon DP $\kappa$ karagenan adalah $91,513 \%$.

\section{KESIMPULAN}

Proses ozonasi menyebabkan depolimerisasi $\kappa$ karagenan yang ditunjukkan dengan penurunan ukuran berat molekul. Hasil penelitian menunjukkan bahwa fungsi linier dari waktu, $\mathrm{pH}$, suhu dan fungsi kuadratik dari $\mathrm{pH}$ dan suhu ozonasi berpengaruh secara signifikan terhadap depolimerisasi $\kappa$-karagenan. Sedangkan semua fungsi interaksi antara variabel bebas tidak memberikan pengaruh yang signifikan. Hasil analisis varian menghasilkan nilai koefisien $\mathrm{R}^{2}=0,98$ yang menunjukkan bahwa hasil eksperimen mendekati prediksi. Hasil optimasi menunjukkan kondisi operasi optimum terjadi pada waktu ozonasi 15 menit, pH 3 dan suhu $25^{\circ} \mathrm{C}$ dengan respon DP sebesar $89,184 \%$.

\section{UCAPAN TERIMA KASIH}

Ucapan terima kasih atas pembiayaan penelitian melalui Hibah Penelitian Riset Pengembangan dan Penerapan (RPP) DIPA UNDIP 2017, dengan No. Surat Penugasan: 275096/UN7.5.1/PG/2017. Penulis juga mengucapkan terima kasih kepada Laboratorium Penelitian Departemen Teknik Kimia Universitas Diponegoro.

\section{DAFTAR PUSTAKA}

Abad, L.V., Kudo, H., Saiki, S., Nagasawa, N., Tamada, M., Fu, H., Muroya, Y., Lin, M., Katsumura, Y., Relleve, L.S., Aranilla, C.T., and DeLaRosa, A.M., (2010), Radiolysis Studies of Aqueous $\kappa-$ Carrageenan, Nuclear Instruments and Methods in Physics Research B, 268, pp. 1607-1612.

Aksoy, D.O. and Sagol, E., (2016), Application of Central Composite Design Method to Coal Flotation: Modelling, Optimization and Verification, Journal Fuel, 183, pp. 609-616.

Bixler, H.J. and Porse, H., (2010), A Decade of Change in the Seaweed Hydrocolloids Industry, Journal of Applied Phycology, 23, pp. 321-335.

Campo, V.L., Kawano, D.F., Silva, D.B.D., and Carvalho, I., (2009), Carrageenans: Biological Properties, Chemical Modifications and Structural Analysis - A Review, Carbohydrate Polymers, 77, pp.167-180.

de Souza, L.A.R., Dore, C.M.P.G., Castro, A.J.G., de Azevedo, T.C.G., de Oliveira, M.T.B., Moura, M.F.V., Benevides, N.M B., and Leite, E.L., (2012), Galactans from the Red Seaweed Amansia multifidaand their Effects on Inflammation, Angiogenesis, Coagulation and Cell Viability, Biomedicine \& Preventive Nutrition, 2, pp. 154-162.

Duan, F., Yu, Y., Liu, Z., Tian, L., and Mou, H., (2016), An Effective Method for the Preparation of Carrageenan Oligosaccharides Directly from Eucheuma cottonii using Cellulase and Recombinant к-Carrageenase, Algal Research, 15, pp. 93-99.

Hadiyanto, H. and Sutrisnohadi, (2016), Response Surface Optimization of Ultrasound Assisted Extraction (UAE) of Phycocyanin from Microalgae Spirulina platensis, Emirates Journal of Food and Agriculture, 28(4), pp. 227-234.

Haijin, M., Xiaolu, J., and Huashi, G., (2003), A Carrageenan Derived Oligosaccharide Prepared by Enzymatic Degradation Containing Anti-tumor Activity, Journal of Applied Phycology, 15, pp. 297303.

Jiao, G., Yu, G., Zhang, J., and Ewart, H.S., (2011), Chemical Structures and Bioactivities of Sulfated Polysaccharides from Marine Algae, Marine Drugs, 9, pp. 196-223.

Kabal'nova, N.N., Murinov, K.Y., Mullagaliev, I.R., Krasnogorskaya, N.N., Shereshovets, V.V., Monakov, Y.B. and Zaikov, G.E., (2001), Oxidative Destruction 
of Chitosan under Effect of Ozone and Hydrogen Peroxide, Journal of Applied Polymer Science, 81, pp. 875-881.

Kalitnik, A.A., Barabanova, A.O.B., Nagorkaya, V.B., Reunov, A.V., Glazunov, V. P., Solov'eva, T.F., and Yermak, I.M., (2013), Low Molecular Weight Derivatives of Different Carrageenan Types and their Antiviral Activity, Journal of Applied Phycology, 25, pp. 65-72.

Karlsson, A. and Singh, S.K., (1999), Acid Hydrolysis of Sulfated Polysaccharides, Desulphation and the Effect on Molecular Mass, Carbohydrate Polymers, 38 (1), pp. 7-15.

Klein, B., Vanier, N.L., Moomand, K., Pinto, V.Z., Colussi, R., da Rosa Zavareze, E., and Dias, A.R.G., (2014), Ozone Oxidation of Cassava Starch in Aqueous Solution at Different pH, Food Chemistry, 155 , pp. 17-173.

Lai, V.M.F., Lii, C.Y., Hung, W.L., and Lu, T.J., (2000), Kinetic Compensation Effect in Depolymerisation of Food Polysaccharides, Food Chemistry, 68, pp. 319-325.

Lemeune, S., Barbe, J.M., Trichet, A., and Guilard, R., (2000), Degradation of Cellulose Models during an Ozone Treatment: Ozonation of Glucose and Cellobiose with Oxygen or Nitrogen as Carrier Gas at Different pH, Ozone Science and Engineering, 22, pp. 447-60.

Lii, C.-Y., Chen, C.-H., Yeh, A.-I., Lai, and V.M.F., (1999), Preliminary Study on the Degradation Kinetics of Agarose and Carrageenans by Ultrasound, Food Hydrocolloids, 13, pp. 477-481

Loures, C.C.A., Alcântara, M.A.K., Filho, H.J.I., Teixeira, A.C.S.C., Silva, F.T., Paiva, T.C.B., and Samanamud, G.R.L., (2013), Advanced Oxidative Degradation Processes: Fundamentals and Applications, International Review of Chemical Engineering, 5, pp. 102-120.

Necas, J. and Bartosikova, L., (2013), Carrageenan: A Review, Veterinarni Medicina, 58, pp. 187-205.

Pomin, V.H. (2010). Structural and Functional Insights into Sulfated Galactans: A Systematic Review, Glycoconj Journal, 27, pp. 1-12.

Prasetyaningrum, A., Ratnawati, R., and Jos, B., (2017a), Effect of Ozonation Process on Physicochemical and Rheological Properties of $\kappa$ Carrageenan, Scientific Study \& Research Chemistry \& Chemical Engineering, Biotechnology, Food Industry, 18(1), pp. 009 - 018.
Prasetyaningrum, A., Ratnawati, R., and Jos, B., (2017b), Kinetics of Oxidative Depolymerization of $\kappa$ carrageenan by Ozone, Bulletin of Chemical Reaction Engineering \& Catalysis, 12(2), pp. 235-242.

Qi, H., Zhang, Q., Zhao, T., Chen, R., Zhang, H., Niu, X., and Li, Z., (2005), Antioxidant Activity of Different Sulfate Content Derivatives of Polysaccharide Extracted from Ulva Pertusa (Chlorophyta) in Vitro, International Journal of Biological Macromolecules, 37, pp. 195-199.

Raman, R. and Doble, M., (2015), к-Carrageenan from Marine Red Algae, Kappaphycus alvarezii - A Functional Food to Prevent Colon Carcinogenesis, Journal of Functional Foods, 15, pp. 354-364.

Ratnawati, R., Prasetyaningrum, A., Wardhani, D.H., (2016), Kinetics and Thermodynamics of UltrasoundAssisted Depolymerization of $\kappa$-Carrageenan, Bulletin of Chemical Reaction Engineering \& Catalysis, 11, pp. 48-58.

Regti, A., Laamari, M.R., Stiriba, S.E., and Haddad, M.E., (2017), Use of Response Factorial Design for Process Optimization of Basic Dye Adsorption onto Activated Carbon Derived from Persea Species, Microchemical Journal 130, pp. 129-136.

Sandhu, H.P.S., Manthey, F., and Simsek, S., (2012), Ozone Gas Affects Physical and Chemical Properties of Wheat Starch (Triticum aestivum L.), Carbohydrate Polymers, 87, pp. 1261-1268.

Seydim, Z.B. and Greene, A.K., (2004), Use of Ozone in the Food Industry, LWT-Food Science and Technology, 37, pp. 453-460.

Silva, F.R.F., Dore, C.M.P.G., Marques, C.T., Nascimento, M.S., Benevides, N.M.B., Rocha, H. A.O., Chavante, S.F., and Leite, E.L., (2010), Anticoagulant Activity, Paw Edema and Pleurisy Induced Carrageenan: Action of Major Types of Commercial Carrageenans, Carbohydrate Polymers, 79, pp. 26-33.

Singh, S.K. and Jacobson, S.P., (1994), Kinetics of Acid Hydrolysis of $\kappa$-Carrageenan as Determined by Molecular Weight (SEC-MALLSRI), Gel Breaking Strength, and Viscosity Measurements, Carbohydrate Polymers, 23, pp. 89-103.

Sun, Y., Yang, B., Wu, Y., Liu, Y., Gu, X., Zhang, H., Wang, C., Cao, H., Huang, L., and Wang, Z., (2015), Structural Characterization and Antioxidant Activities of $\kappa$-Carrageenan Oligosaccharides Degraded by Different Methods, Food Chemistry, 178, pp. 311-318. 
Taghizadeh, M.T. and Abdollahi, R., (2015), Influence of Different Degradation Techniques on the Molecular Weight Distribution of $\kappa$-Carrageenan. International Journal of Biochemistry and Biophysics, 3, pp. 25-33.

Vreeman, H.J., Snoeren, T.H.M., and Payens, T.A.J., (1980), Physicochemical Investigation of $\kappa-$ Carrageenan in the Random State, Biopolymers, 19, pp. 1357-1354.

Vuong, Q.V., Golding, J.B.,Nguyen, M.H. and Roach,P.D., (2011), Production of Caffeinated and Decaffeinated Green Tea Catechin Powders from Underutilised Old Tea Leaves, J. Food Eng, 110, pp. $1-8$.

Wang, W., Zhang, P., Yua, G.L., Li, C.X., Hao, C., Qi, X., Zhang, L.J., and Guan, H.S., (2012), Preparation and Anti-influenza A Virus Activity of $\kappa$ Carrageenan Oligosaccharide and Its Sulphated Derivatives, Food Chemistry, 133, pp. 880-888.

Wang, Y., Hollingsworth, R.I., and Kasper, D.L., (1999), Ozonolytic Depolymerization of Polysaccharides in Aqueous Solution, Carbohydrate Research, 319, pp. 141-147.

Wijesekara, I., Pangestuti, R., and Kim, S.K., (2011), Biological Activities and Potential Health Benefits of Sulfated Polysaccharides Derived from Marine Algae, Carbohydrate Polymers, 84, pp. 14-21.

Wu, S.J., (2012), Degradation of $\kappa$-Carrageenan by Hydrolysis with Commercial $\alpha$-Amylase, Carbohydrate Polymers, 89, pp. 394-396.
Yamada, T., Ogamo, A., Saito, T., Uchiyama, H., and Nakagawa, Y., (2000), Preparation of O -Acylated Low-molecular-weight Carrageenans with Potent Anti-HIV Activity and Low Anticoagulant Effect, Carbohydrate Polymers, 41, pp. 115-120.

Yao, Z., Wu, H., Zhang, S., and Du, Y., (2014), Enzymatic Preparation of $\kappa$-Carrageenan Oligosaccharides and their Anti-Angiogenic Activity, Carbohydrate Polymers, 101, pp. 359-367.

Yuan, H. and Song, J., (2005), Preparation, Structural Characterization and in Vitro Antitumor Activity of kappa -Carrageenan Oligosaccharide Fraction from Kappaphycus striatum, Journal of Applied Phycology, 17, pp. 7-13.

Zhang, Q.A., Zhang, Z.Q., Yue, X.F., Fan, X.H., Li, T., Chen,S.F., (2009), Response Surface Optimization of Ultrasound-Assisted Oil Extraction from Autoclaved Almond Powder, Food Chem, 116, pp. 513-518.

Zhou, G., Yao, W., and Wang, C., (2006), Kinetics of Microwave Degradation of $\lambda$-carrageenan from Chondrus Ocellatus, Carbohydrate Polymers, 64, pp. 73-77.

Zúñiga, E., Matsuhiro, B., and Mejías, E., (2006), Preparation of a Low-Molecular Weight Fraction by Free Radical Depolymerization of the Sulfated Galactan from Schizymenia binderi (Gigartinales, Rhodophyta) and Its Anticoagulant Activity, Carbohydrate Polymers, 66, pp. 208-215. 